\title{
Jean-Paul Goujon, Les Loisirs de la poste: lettres inédites d'Edouard Dubus
}

\section{Isabella Giovinazzo}

\section{(2) OpenEdition}

1 Journals

\section{Edizione digitale}

URL: https://journals.openedition.org/studifrancesi/38136

DOI: 10.4000/studifrancesi.38136

ISSN: 2421-5856

\section{Editore}

Rosenberg \& Sellier

\section{Edizione cartacea}

Data di pubblicazione: 15 décembre 2004

Paginazione: 640

ISSN: 0039-2944

\section{Notizia bibliografica digitale}

Isabella Giovinazzo, «Jean-Paul Goujon, Les Loisirs de la poste: lettres inédites d'Edouard Dubus», Studi Francesi [Online], 144 (XLVIII | III) | 2004, online dal 30 novembre 2015, consultato il 08 mai 2021. URL: http://journals.openedition.org/studifrancesi/38136; DOI: https://doi.org/10.4000/studifrancesi. 38136

Questo documento è stato generato automaticamente il 8 mai 2021.

\section{(c) (i) $\odot$}

Studi Francesi è distribuita con Licenza Creative Commons Attribuzione - Non commerciale - Non opere derivate 4.0 Internazionale. 


\title{
Jean-Paul Goujon, Les Loisirs de la poste: lettres inédites d'Edouard Dubus
}

\author{
Isabella Giovinazzo
}

\section{NOTIZIA}

JEAN-PAUL Goujon, Les Loisirs de la poste: lettres inédites d'Edouard Dubus, «Histoires

Littéraires», 2003 no. 14, pp. 89-107.

1 L'articolo presenta un rapido ritratto del poeta, fisico, spirituale e letterario, citando le amicizie e i contatti con il mondo letterario oltre alla sua particolare collocazione nell'ambito del movimento poetico del periodo 1885-90, vale a dire la tendenza esoterica e occultista del simbolismo, per introdurre alcuni inediti tratti dalla corrispondenza dell'autore e diretti a Elias Poncin de Linchet, Leon Dechamps, A . G. Hocq, Jean Rictus, Gabriel Randon e J. K. Huysmans. L'insieme più numeroso è costituito dalle lettere dirette a Elias (dieci), giovane attrice amata dal poeta che però contava tra i suoi ammiratori anche altri esponenti dell'ambiente letterario, dalle quali si evidenzia una certa ambiguità di Dubus nell'ambito delle relazioni sentimentali. Gli altri testi, relativi ai contatti letterari e professionali, ritraggono i vari aspetti della personalità $e$ dell'attività del poeta occultista, giornalista ma anche burocrate e avvocato, eclettismo tipico dell'epoca. 